\title{
ISKON Rotary Intersection on S.G Highway in Ahmedabad as Signalized Intersection - A Case Study
}

\author{
Alpana Jha \\ Lecturer (Civil Engineering), Government Polytechnic, Ahmedabad, Gujarat, India
}

\begin{abstract}
ISKON Rotary Intersection on S.G highway in Ahmedabad is a four-legged rotary intersection and has potentially failed as flow is much higher than the capacity of rotary. Rotary is oversaturated and the LOS is F. Intersection performance is evaluated if it is converted to signalized intersection. Traffic flow coming from sharkhej, Gandhinagar, Bopal and Satellite road was recorded for the intersection. Traffic consists of car, auto-rickshaw, bus, two wheelers and bicycle. Data for Lane Group, Approach volume, Intersection volume at ISKON intersection is collected. ISKON intersection volume is $6107 \mathrm{veh} / \mathrm{hr}$. Maximum approach volumes are on north approach i.e. from Theltej side which is $1770 \mathrm{veh} / \mathrm{hr}$. It is $29 \%$ of total intersection volume. Minimum approach volume is on west side i.e. from Bopal side which is 1419 veh / hr. It is $23 \%$ of total intersection volume. A four phase signal system is selected for the intersection. Amber time, Pedestrian crossing time Optimal cycle length and Delay is Determined. Even if ISKON rotary intersection is converted to signalized intersection, LOS is $E$ and $D$ which is not very much desired. So conversion of ISKON rotary intersection to signalized intersection is not justified.
\end{abstract}

Keywords: Rotary Intersection, signalized intersection, Level of service, Optimum cycle length

\section{Introduction}

For more than three decades modern roundabouts have been used successfully throughout the world as a junction control device. Evaluation of junction capacity is very important since it is directly related to delay, level of service, accident, operation cost, and environmental issues. Ahmedabad also has its share of roundabouts. There are three legs; four legs; five legs and six legs roundabouts in Ahmedabad.

It is seen that Iskon Rotary Intersection on S.G highway in Ahmedabad has potentially failed as flow is much higher than the capacity of rotary. Rotary is oversaturated and the LOS provided is F. Here we will evaluate the intersection performance if it is converted to signalized intersection.

ISKON Intersection: This is four-legged rotary intersection. During peak hours (morning peak), the intersection gets over saturated (Demand more than capacity). The road surface condition at study approaches is good, affecting the speed of vehicles. Traffic flow was recorded for the intersection, coming from sherkhej, Gandhinagar, Bopal and Satellite road. Traffic consists of car, auto-rickshaw, bus, two wheelers and bicycle.

Table 1 shows the Lane Group, Approach volume, Intersection volume at ISKON intersection.

Detailed collected data at ISKON intersection are shown separately. It shows ISKON intersection volume is 6107 veh/hr. Maximum approach volumes at ISKON intersection is on north approach i.e. from Theltej side which is $1770 \mathrm{veh} / \mathrm{hr}$. It is $29 \%$ of total intersection volume. Minimum approach volume is on west side i.e from Bopal side which is $1419 \mathrm{veh} / \mathrm{hr}$. It is $23 \%$ of total intersection volume.

Table 1: Lane Group, Approach volume, Intersection volume at ISKON intersection

\begin{tabular}{|c|c|c|c|c|c|}
\hline \multicolumn{6}{|c|}{ Name of intersection: ISKON Intersection } \\
\hline & & Peak survey & .00 A.M - 11.00 A.M & & \\
\hline Sr. No. & Approach & Lane Group & $\begin{array}{c}\text { Lane Group volume } \\
(\text { veh/h) }\end{array}$ & $\begin{array}{c}\text { Approach volume } \\
(\text { veh } / h)\end{array}$ & $\begin{array}{c}\text { Intersection volume } \\
(\mathrm{veh} / \mathrm{h})\end{array}$ \\
\hline 1. & \multirow{3}{*}{ NORTH } & Left turn & 175 & \multirow[b]{3}{*}{1770} & \multirow{12}{*}{6107} \\
\hline 2. & & Through & 1105 & & \\
\hline 3. & & Right turn & 490 & & \\
\hline 4. & \multirow{3}{*}{ SOUTH } & Left turn & 141 & \multirow[b]{3}{*}{1423} & \\
\hline 5. & & Through & 995 & & \\
\hline 6. & & Right turn & 287 & & \\
\hline 7. & \multirow[b]{3}{*}{ EAST } & Left turn & 183 & \multirow[b]{3}{*}{1495} & \\
\hline 8. & & Through & 916 & & \\
\hline 9. & & Right turn & 396 & & \\
\hline 10. & \multirow{3}{*}{ WEST } & Left turn & 144 & \multirow[b]{3}{*}{1419} & \\
\hline 11. & & Through & 991 & & \\
\hline 12 & & Right turn & 284 & & \\
\hline
\end{tabular}

Source: Traffic survey 


\section{International Journal of Science and Research (IJSR) \\ ISSN (Online): 2319-7064 \\ Index Copernicus Value (2013): 6.14 | Impact Factor (2014): 5.611}

\section{Design of Signalized Intersection}

A four phase signal system is selected for the intersection. The geometric parameter of the intersection is as mentioned in table 2

Table 2: Geometric details for Case study Intersection

\begin{tabular}{|c|c|c|c|c|c|}
\hline \multicolumn{6}{|c|}{ Name of intersection: ISKON Intersection } \\
\hline Approach & $\begin{array}{l}\text { Lane } \\
\text { Group }\end{array}$ & $\begin{array}{l}\text { No. of } \\
\text { lanes } \\
\text { Per lane } \\
\text { Group }\end{array}$ & $\begin{array}{l}\text { Width } \\
\text { per } \\
\text { lane } \\
(\mathrm{m})\end{array}$ & $\begin{array}{l}\text { Approach } \\
\text { Width } \\
\text { (m) }\end{array}$ & $\begin{array}{l}\text { Approach } \\
\text { Grade } \\
(\%)\end{array}$ \\
\hline \multirow{3}{*}{ North } & $\begin{array}{l}\text { Left } \\
\text { turn }\end{array}$ & 1 & 3 & \multirow{3}{*}{28} & \multirow{3}{*}{0} \\
\hline & Through & 2 & 3 & & \\
\hline & $\begin{array}{l}\text { Right } \\
\text { turn }\end{array}$ & 1 & 3 & & \\
\hline \multirow{3}{*}{ South } & $\begin{array}{l}\text { Left } \\
\text { turn }\end{array}$ & 1 & 3 & \multirow{3}{*}{28} & \multirow{3}{*}{0} \\
\hline & Through & 2 & 3 & & \\
\hline & $\begin{array}{l}\text { Right } \\
\text { turn }\end{array}$ & 1 & 3 & & \\
\hline \multirow{3}{*}{ East } & $\begin{array}{l}\text { Left } \\
\text { turn }\end{array}$ & 1 & 3 & \multirow{3}{*}{26} & \multirow{3}{*}{0} \\
\hline & Through & 2 & 3 & & \\
\hline & $\begin{array}{l}\text { Right } \\
\text { turn }\end{array}$ & 1 & 3 & & \\
\hline \multirow{3}{*}{ West } & $\begin{array}{l}\text { Left } \\
\text { turn }\end{array}$ & 1 & 2.5 & \multirow{3}{*}{18} & \multirow{3}{*}{0} \\
\hline & Through & 1 & 2.5 & & \\
\hline & $\begin{array}{l}\text { Right } \\
\text { turn }\end{array}$ & 1 & 2.5 & & \\
\hline
\end{tabular}

Source: Traffic survey

Approach width $=$ one direction lane group width + median width + another direction flow lane group width

Approach width $($ North $)=12+4+12=28$

Approach width (South) $=12+4+12=28$

Approach width (East) $=12+2+12=26$

Approach width (West) $=7.5+3+7.5=18$

Phase I- North - South through

Phase II- North -South right turn

Phase III- East-west through

Phase IV- East-west right turn

\section{Determination of Amber Time}

Amber time is determined using the dilemma zone analysis. The amber time for phase I and III is determined using equation

$$
\tau \min =t r+\frac{v}{2} d+\frac{w+L}{v}
$$

Where $\mathrm{tr}=$ perception reaction time

$\mathrm{V}=$ design speed $=45 \mathrm{Kmph}=12.5 \mathrm{~m} / \mathrm{s}$

$\mathrm{d}=$ comfortable deceleration rate $=4 \mathrm{~m} / \mathrm{s}$

$\mathrm{w}=$ width of intersection which the vehicle of length $\mathrm{L}$ can cross during amber time

$\mathrm{L}=$ Length of vehicle.

thus $\operatorname{ta}(\mathrm{I})=5 \operatorname{secs}$

$\operatorname{ta}(\mathrm{III})=5 \mathrm{secs}$

\section{Determination of Pedestrian Crossing Time}

The IRC: 93-1985 suggests the use of the following equation for determining tp, the time to be allotted for pedestrian crossing.

$$
t p=7+\frac{w}{1.2}
$$

Where $\mathrm{w}$ is the width of road in $\mathrm{m}$ which the pedestrians have to cross and tp is the crossing time in seconds.

Thus $\operatorname{tp}(\mathrm{I})=29 \mathrm{~s}$.

$\operatorname{tp}(\mathrm{III})=30 \mathrm{~s}$

\section{Determination of Optimal Cycle Length}

In order to obtain optimal cycle length $\mathrm{Co}$, first the saturation flows is calculated and then the critical flow ratios are obtained. The saturation flows are calculated as per IRC 93-1985

Table 4: Determination of saturation flow

\begin{tabular}{|c|c|c|}
\hline Approach & Width $(\mathrm{m})$ & $\begin{array}{c}\text { Saturation flow in PCU/ } \\
\text { ( } \text { of green })\end{array}$ \\
\hline $\begin{array}{c}\text { Eastbound through } \\
\text { and left-turn } \\
\text { approaches }\end{array}$ & $3 * 3=9$ & $525 * 9=4725$ \\
\hline $\begin{array}{c}\text { Eastbound Right-turn } \\
\text { approaches }\end{array}$ & 3 & 1850 \\
\hline $\begin{array}{c}\text { Westbound through } \\
\text { and left-turn } \\
\text { approaches }\end{array}$ & $3 * 2=6$ & $525 * 6=3150$ \\
\hline $\begin{array}{c}\text { Westbound Right-turn } \\
\text { approaches }\end{array}$ & 3 & $525 * 9=4725$ \\
\hline $\begin{array}{c}\text { Northbound through } \\
\text { and left-turn } \\
\text { approaches }\end{array}$ & $3 * 3=9$ & 1850 \\
\hline $\begin{array}{c}\text { Northbound Right- } \\
\text { turn approaches }\end{array}$ & 3 & $525 * 9=4725$ \\
\hline $\begin{array}{c}\text { Southbound through } \\
\text { and left-turn } \\
\text { approaches }\end{array}$ & $3 * 3=9$ & 1850 \\
\hline $\begin{array}{c}\text { Southbound Right- } \\
\text { turn approaches }\end{array}$ & 3 & \\
\hline
\end{tabular}

Based on the above saturation flows and the phasing scheme, the critical flow ratios are calculated as follows:

Table 5: Determination of critical flow ratios

\begin{tabular}{|c|l|c|}
\hline Phase & \multicolumn{1}{|c|}{ Flow ratios } & Critical flow ratios \\
\hline I & $\begin{array}{l}1281 / 4725=0.27,1137 / 4725 \\
=0.24\end{array}$ & 0.27 \\
\hline II & $\begin{array}{l}490 / 1850=0.26,287 / 1850= \\
0.16\end{array}$ & 0.26 \\
\hline III & $\begin{array}{l}1099 / 4725=0.23, \\
1136 / 4725=0.24\end{array}$ & 0.24 \\
\hline IV & $\begin{array}{l}396 / 1850=0.21,284 / 1850= \\
0.15\end{array}$ & 0.21 \\
\hline & Total & 0.98 \\
\hline
\end{tabular}


The total time lost,

$$
L=\sum l s^{i}+l m^{i}+l r^{i}
$$

Or, $\mathrm{L}=18 \mathrm{~s}$.

Hence Optimal cycle time as given by Webster

$$
c o=\frac{1.5 L+5}{1-\sum_{i=1}^{p}(v / s)_{c r}^{i}}
$$

Thus first estimate of $\mathrm{Co}=160$ secs.

The final step is to determine the phase lengths and check for their adequacy with regard to pedestrian crossing times( if green time plus amber time plus all red time for a phase is greater than or equal to the pedestrian crossing time required for that particular phase, then the green time for that phase is adequate.

The total green time (without the amber time) available for distribution among the four phases is

$=160-4 * 5=140$ secs

Green time $=$ critical flow ratio $/ \sum$ critical flow ratio

Table 6: Determination of Green time

\begin{tabular}{|c|c|c|c|c|}
\hline Phase & Green $(s)$ & Amber $(s)$ & $t p$ & $\begin{array}{c}\text { Is green adequate from tp } \\
\text { consideration }\end{array}$ \\
\hline I & 39 & 5 & 29 & Yes $(39+5=44>29)$ \\
\hline II & 37 & 5 & 0 & Yes \\
\hline III & 34 & 5 & 30 & Yes \\
\hline IV & 30 & 5 & 0 & Yes \\
\hline
\end{tabular}

Final Signal timings for the intersection are as follows:

Cycle Length $=167$ Secs

Phase I, Green time - 40 Secs.

Amber time- 5 Secs.

Phase II, Green time - 39 Secs.

Amber time- 5 Secs

Phase III, Green time - 36 Secs.

Amber time- 5 Secs

Phase IV, Green time - 32 Secs.

Amber time- 5 Secs

There is no all red time.

\section{Delay analysis of signalized intersection}

Delay analysis is done as per Webster Equation

$$
D=0.9\left[\frac{c(1-\lambda)^{2}}{2(1-\lambda x)}+\frac{(x)^{2}}{2 q(1-x)}\right]
$$

Where, $\lambda=\mathrm{g} / \mathrm{c}$

$\mathrm{q}=$ flow $/(1.1125 * 3600) \mathrm{veh} / \mathrm{sec}$

$\mathrm{x}=\mathrm{q} / \lambda . \mathrm{S}$

$\mathrm{S}=$ Saturation $/ 3600 \mathrm{PCU} / \mathrm{sec}$

Delay $($ North $)=67.28 \mathrm{sec}$.

Delay $($ South $)=52.36 \mathrm{Sec}$.
Delay $($ East $)=59.14 \mathrm{Sec}$.

Delay $($ West $)=61.94 \mathrm{Sec}$

Table 7: Comparison between delay and LOS

\begin{tabular}{|c|c|c|}
\hline Approach & Delay & LOS \\
\hline North & $67.28 \mathrm{sec}$ & $\mathrm{E}$ \\
\hline South & $52.36 \mathrm{Sec}$. & $\mathrm{D}$ \\
\hline East & $59.14 \mathrm{Sec}$. & $\mathrm{E}$ \\
\hline West & $61.94 \mathrm{Sec}$ & $\mathrm{E}$ \\
\hline
\end{tabular}

\section{Summary}

From the above analysis we can see that even the ISKON rotary intersection is converted to signalized intersection, LOS is $\mathrm{E}$ and $\mathrm{D}$ which is not very much desired. So conversion of ISKON rotary intersection to signalized intersection is not justified. The better option is to convert the rotary intersection to Grade separated intersection.

\section{References}

[1] Chakroborty Partha, Das Animesh, Principles of Transportation Engineering, Prentice Hall of India, New Delhi, 2005.

[2] Highway Capacity Manual 2000 by Transportation Research Board, National Research council, Washington D.C

[3] Patil Gopal R (2002). A Dissertation on "Capacity analysis of signalized Intersection in Developing Countries"

[4] Chhaya Arun R (2004), A Dissertation on "Adaptive Traffic Control Signal Design for an isolated intersection"

[5] Chandra S., Sikdar, P. K. and Kumar Virendra (1996), "Level of Service for Mixed Traffic at Signalized Intersections", Journal of the Institute of Engineers (India), Volume -77, pp. 12-16.

[6] IRC 93-1985, Guidelines on Design and Installation of Road Traffic Signals, Indian Roads Congress, New Delhi, 1985 